\title{
Comparative analysis of commorientes - a South African perspective: Part 2
}

\author{
Linda Schoeman-Malan \\ $B A L L D$ \\ Professor in Private law, University of Pretoria
}

\section{OPSOMMING \\ Hedendaagse analise van Commorientes}

Die gelyktydige afsterwe van 'n familie, of lede van 'n gesin as gevolg van 'n katastrofiese gebeurtenis, het 'n direkte invloed op die aanwysing van begunstigdes en die bereddering van die oorledenes se boedels. Dit blyk dat natuurrampe en ander rampe aan die toeneem is. Die gelyktydige dood van families en verwante kan 'n geskil ontketen oor die verdeling van die boedels (van persone wat gelyktydig gesterf het).

Die term 'commorientes' word in die vorige deel van hierdie artikel ontleed en die leerstuk word bespreek soos dit gemanifesteer het in die Romeinse siviele reg en die resepsie daarvan in die Romeins-Hollandse reg. Daarteenoor word die leerstuk in die Engelse gemeenregtelike jurisdiksies bespreek en vergelyk met die Romeins gebaseerde siviele reg wat Europese stelsels beïnvloed het. Die verskillende benaderings om 'gelyktydige sterftes' te bewys, word bespreek. Waar die AngloAmerikaanse stelsels die volgorde van sterftes reguleer deur wetgewing (siviele kodes) en gebruik maak van sekere vermoedens in die geval van onsekerheid oor die spesifieke volgorde, volg die Engelse gemeenregtelike jurisdiksies die benadering dat die volgorde van dood 'n feitevraag is wat telkens in die lig van die omstandighede wat gelei het tot die dood, bewys en beantwoord moet word. Die volgorde van dood op 'n oorwig van waarskynlikhede te bewys.

In hierdie, die vervolg van bogenoemde artikel, word die historiese aanloop tot hedendaagse benadering en die invloed daarvan op die SuidAfrikaanse reg onder die loep geneem. Uit enkele Suid-Afrikaans gerapporteerde hofsake oor die onderwerp, blyk dit dat die 'tradisionele gemenereg' gevolg word en dat die volgorde van dood ' $n$ feitevraag is. Wetgewing wat in ander jurisdiksies in die loop van die twintigste eeu geïmplementeer is om voorsiening maak vir 'n vermoedens van gelyktydige afsterftes, word toegelig. Daar word aangetoon dat statutêre ontwikkelings in ander gemeenregtelike jurisdiksies hoofsaaklik ten doel het gesamentlike eiendomsreg (joint tenacies) te reguleer. Ander ontwikkelings hou verband met klousules wat vir substitusie voorsiening maak (in geval van vooroorledenes) en 'gelyktydige afsterf' klousules wat deur testateurs gebruik word by die verlyding van testamente. Ten slotte word 'n kritiese evaluering van die verskillende stelsels gedoen en aangetoon dat Suid-Afrika nie 'n behoefte het aan hervorming nie en waarskynlik die billikste en regverdige benadering van 'hy wat beweer moet bewys' volg.

Continued from 2017 De Jure 17(1).

How to cite: Schoeman-Malan 'Comparative analysis of commorientes - a South African perspective: Part 2 ' 2017 De Jure 378-395

http://dx.doi.org/10.17159/2225-7160/2017/v50n2a10 


\section{South African Law}

Where does South Africa stand in its approach towards simultaneous deaths? This question should be answered against the backdrop of influences by both civil and common law on our legal system. ${ }^{1}$ In general the South Africa law of succession reflects the principles of a mixed jurisdiction par excellence. ${ }^{2}$ Tetley describes it as follows: ${ }^{3}$

In the new Republic of South Africa, where South African legislation and precedents are lacking, Roman-Dutch and English sources are given approximately equal weight, in a kind of pragmatism. There is a considerable respect for both the institutional writers and more recent authors on RomanDutch law (a civilian trait), mixed with a view of judicial precedent as of very great importance (a common-law characteristic).

Thus, where aspects of the Roman-Dutch law principles were initially retained, ${ }^{4}$ the English law blended with Roman-Dutch law in the aftermath of Britain's occupation of the Cape in $1806 .^{5}$ As far as the 'simultaneous deaths' principle is concerned the position is explained as follows by Corbett and others: 6

Unlike Roman law, Roman-Dutch law, English law and the laws of most Continental countries, South African law has no presumptions as to survivorship, based on age, where several persons were killed in the same catastrophe, such as (a) shipwreck, an aeroplane crash, a motor vehicle collision. ${ }^{7}$

The reference (in the quote) to 'has no presumptions as to survivorship' is a rejection of the codified Continental law, ${ }^{8}$ and the statutory amendment of the English law (after 1925). ${ }^{9}$ While South Africa has no statutory provision that deals with 'simultaneous deaths' or 'survivorship' and although the courts would normally revert to the Roman-Dutch law in situations where legislation lacks, it appears that the

1 See Tetley (ULR) 597 ff; Lee (1946) 369; Roeleveld 33; Schoeman 108-109; Zimmermann and Visser 3 n 16; Corbett et al 5; Boezaart 157; Du Toit 278 ff; De Waal and Schoeman-Malan 12.

2 See Lee (1946) 369; Zimmermann and Visser 3 n 16 and 2-13; see also Thomas 133-155.

$3 \quad(U L R) 605$.

4 Tetley $(U L R)$ 591; The British rulers retained Roman-Dutch law, but the law at the Cape came under increased English legal influence as the British pursued an aggressive policy of Anglicisation from 1820 onward. See also Du Toit 278 .

5 Tetley $(U L R) 605$.

6 See also Roeleveld $31 \mathrm{ff}$ and Schoeman $108 \mathrm{ff}$.

7 Own emphasis.

8 See also Williams (YLR) 156 who explains that the Cape was untouched by the new French codification, which had been introduced in 1811 in the Netherlands putting an end to the so-called Roman-Dutch law in that country.

9 As seen above, the traditional English law with regard to 'simultaneous deaths' was altered by the 'section 184 presumption' in 1925. 
courts have opted to follow judicial precedent rather than the RomanDutch law. ${ }^{10}$

The foundation of the South African 'commorientes' principle is rather vague and is found in case law. ${ }^{11}$ There are only five reported cases dealing with 'commorientes' and they are all dated after 1940. It is not clear when, how, where and if the change from the 'presumption orientated civil law approach' (Roman-Dutch law), to the 'traditional English common law approach' took place. In earlier case law reference is vaguely made to Roman-Dutch law and to common law cases. ${ }^{12}$ In Nepgen $v$ Van Dyk reference was made to the 'presumption rule' and it was rejected as not being part of South African law. ${ }^{13}$ Lansdown JP pointed out:

... that there was no presumption in our law such as that provided for in the English Law of Property Act 1925, s 184, which enacted that if it was uncertain which of two persons survived the other, the younger was deemed to have survived the elder.

The case, however, deals with a situation where two unrelated persons died in an accident and one was the beneficiary of the other in a will. ${ }^{14}$ In Ex parte Martienssen, it was presumed that a mother and her daughter died simultaneously by drowning when their lifeboat capsized. ${ }^{15}$ The sequence of death could not be proved. The court came to the conclusion that as it would make no difference what the order of death is, they have consequently died together.

The case Ex parte Graham, is regarded as the leading case in South Africa on 'commorientes'. The court had to deal with the simultaneous deaths (or not) of a mother and her son and the interpretation of the word 'predeceased' in the will. ${ }^{16}$ The court reflected on previous case law

10 The common law as it was applied in England before 1925. See also Murray 365; Corbett et al 5; Boezaart 157; De Waal and Schoeman-Malan 12 and Du Toit 278 ff and Folkerth (OSL) 684-5.

11 Nepgen $v$ Van Dyk 1940 EDL 123; Ex parte Martienssen 1944 CPD 139; Ex parte Bagshaw 1942 (2) PH F77; Ex parte Chodos; Ex parte Graham 19634 SA 145 (D). Recently another case was withdrawn: Smith v Pretorius [2012] ZAFSHC 161.

12 See Underwood $v$ Wing and Wing $v$ Angrave.

13 The court was referred to Voet 36115 and the English common law case Wing $v$ Angrave. See also Roeleveld 36.

14 Own emphasis. There is no presumption of survivorship, where the parties are not related so as to be able to take from each other on intestacy.

15 'Presume' does not refer to 'a presumption' but to 'an assumption' in this context. See Murray 365. The court was referred to D 24523 and D 345 10. See Roeleveld 36-37. Voet 345 3, refers to certain presumptions, after he made the statement that, generally speaking, where people die together in a single catastrophe, no one is deemed to have survived another, unless such is proved.

16 They passed in a plane crash. 
on this topic and rejected any 'presumptions' with reference to Nepgen's case by stating as follows: ${ }^{17}$

It seems to me that the approach adopted in Nepgen $v$ van Dyk is the proper one. There the Court examined the facts to see if there was any evidence to support a conclusion that the deaths were not simultaneous. In the present case, we are concerned with the crash of an aircraft and the evidence is that the aircraft crashed in a swamp and in any event, there is no ground for believing that death would have overtaken them in the usual course of mortality.

The court came to the conclusion that the presumptions have not been followed in previous case law and found that even if the presumptions in fact did form part of the Roman-Dutch Law, that 'it [is] not necessary or desirable to slavishly follow such completely artificial reasoning in modern times'. ${ }^{18}$ The court emphasises that the general rule is that there is no presumption (to prove the order of death). ${ }^{19}$

The South African position can subsequently be explained as an uncodified system, which revert to the traditional English common law. Whenever the order of death of related people is in dispute, the sequence of death remains a factual question that must be established by evidence. ${ }^{20}$ It seems from case law that the South African courts had failed to accurately investigate the differences between the civil law and common law jurisdictions. ${ }^{21}$

At the time when these cases were heard in the 1940's the RomanDutch law had long been replaced by the Dutch Civil Code in The Netherlands and the 'traditional common law' had been replaced in England by section 184 of the Law of Property Act. In Boberg's Law of Persons and Family ${ }^{22}$ it is explained that although there is in principle no presumption of death, there is one in practise. ${ }^{23}$ The use of words 'presume, incline and assume' sometimes contributes to ambiguity in the common law as it is understood (confused) by some as if there in fact is a presumption of simultaneous deaths. It seems as if the principle of equity could have counteracted and influenced the operation of the

17 (n 28). Voet 361 16. See Folkerth (OSLJ) 684 explains that the no presumption rule requires proof to show survival.

18 Own emphasis.

19 Roeleveld 45.

20 The traditional common law approach as followed in Underwood $v$ Wing; Wing $v$ Angrave; Matter of Burza; Gray v Sawyer; Matter of Estate of Hughes 735 SW 2d 787 (Missouri Court of Appeals 1987).

21 For common law jurisdictions see also Hunter 928; Sherman 42; Von Madai 373; Benas and O K F (MLR) 88-90; Folkerth (OSLJ) 684 and Nótári and Papp $(F J) 12$.

22 Van Heerden et al Boberg's Law of Persons and Family (1999) 56. Other similar general 'presumptions of death' are also rejected in South Africa. See De Bruin 'Presumption of Death - It's Legal Consequences' 1978 SALJ 577; Council of Europe 'Principles Concerning Missing Persons and the Presumption of Death' 2010 Council of Europe Publications 1-24.

23 56. See Tracy and Adams (MLR) 801 ff; De Bruin 577; De Beer 8; LRCSA 89; Corbett et al 5; Boezaart 157; Council of Europe 1-24. 
common-law rules in cases dealing with 'commorientes'. Roeleveld explains that all systems have the purpose of serving equity and achieving certainty. 24

\section{Critical Analysis of Civil Law and Common Law Approaches}

\section{Introduction}

As seen above the difference in the approaches in the civil and common law jurisdictions towards 'simultaneous deaths' sometimes result in ambiguity. Furthermore, survival by seconds by one victim, can change the distribution of the estates. Tetley explains the underlining differences in the methodologies that the civil law and common law follow: ${ }^{25}$

Civil law codes and statutes are concise (le style français) while common law statutes are precise (le style anglais). Indeed, civil law statutes provide no definitions, and state principles in broad, general phrases. Common law statutes, on the other hand, provide detailed definitions, and each specific rule sets out lengthy enumerations of specific applications or exceptions, preceded by a catch-all phrase and followed by a demurrer such as 'notwithstanding the generality of the foregoing. 26

These dissimilarities, between civil law and common law, are evidently reflected in the 'commorientes' doctrine. ${ }^{27}$

However, regardless of whether the civil law or common law approach is applied, the first step in determining the order of deaths is, to establish whether the one victim survived the other. The party who claims to benefit from the 'first dying commorient' bears the burden to prove survival. $^{28}$ In all jurisdictions, whenever the order of death can be established, any uncertainty falls away and the division of the estates will follow the sequence of deaths. ${ }^{29}$ Only when it is not possible (uncertainty surrounds the deaths) to prove the order of deaths and establish same, the different approaches (between the civil law and common law)

2449

25 Tetley $(U L R) 613$.

26 615. Common law statutes have to be read against a case law background, while civil law codes and statutes are the primary source of law.

27 See also Neuhaus 'Legal Certainty versus Equity in the Conflict of Laws' 1963 Duke Law 795 ff; Zander The Law-Making Process (2015) 132-139 explains the differences between the French law and the English law.

28 See Folkerth (OSLJ) 684; Tracy and Adams (MLR) $804 \mathrm{ff}$; Mee (NILQ) $178 \mathrm{ff}$ for a detailed discussion of the burden of proof. See also Orji $(C P L)$ who explains that this is also the position when s 184 of the Property Act is applied. In New Zealand, the burden of proof is one of beyond reasonable doubt: See s 3(1) Simultaneous Deaths Act 1958.

Own emphasis. See also Gallanis 198. 
become pertinent. Kiernan remarks as follows on disputes that might arise on the subject of simultaneous deaths: ${ }^{30}$

More importantly for some people is the effect on inheritance provisions either under the will or subject to the intestacy rules. This can result in a fine analysis of the time of death to see if there is any indication that one deceased may in fact have died later - no matter how short a time is involved - which might impact on the way property passes under a will or intestacy. ${ }^{31}$

As seen above, the differences between the approaches towards 'commorientes', in, (i) the traditional common law, (ii) the changed (or altered) common law and (iii) the civil law, become pertinent when the sequence of death still remains 'uncertain' and cannot be proved. ${ }^{32}$ In situations of uncertainty the civil law 'presumptions' will serve as evidence (replace proof) of the sequence of death, while the common law will not make use of any presumptions and will assume that the departed had died simultaneously. 33

\section{Criticism Against Civil and Common Law Approaches}

Criticism on the topic of 'simultaneous deaths' is comprehensive as it cuts through all approaches toward 'commorientes'. Disapproval and justification involve thorough scrutinising of all approaches i.e. the civil law, the English traditional common law and the amended statutory directives. ${ }^{34}$ To explain the extent of criticism the apposite quotation by Middleton JA in the 1925 case Bennett $v$ Peattie can be used as a point of departure: 35

The rules of the Common Law and the rules of the Civil Law upon the subject of survivorship are alike illogical and unsatisfactory. Where upon the death of two the right depends upon survivorship, and the whole fund must go to one or the other according to the determination as a question of fact that one person killed in a common accident drew his last breath a moment after the other expired, the difficulty of the inquiry and the unsatisfactory nature of the result are obvious. ${ }^{36}$

30 'Simultaneous Deaths' http://clarkekiernan.com/contentious-probate/ simultaneous-deaths (accessed 10-09-2016). See also Ryan (WLLR) 1517 1518 and Capron and Kass (UPLR) 89-90.

31 Own emphasis.

32 See Underwood $v$ Wing; Olson $v$ Estate of Rustad. See also Conway and Bertsche (FLR) 18 ff; Haneman and Booth (NLR) 451-471. For SA law see Roeleveld 33 ff; Schoeman 111; for Northern Ireland see Mee (NILQ) 171 ff; NILC; Nótári and Papp (FJ) 12 ff for the civil law in general and Lazarus (LLR) 363 for Louisiana.

33 Own emphasis.

34 LRCSA (1985) 3-37.

35 See also Tracy and Adam (MLR) 807.

36 Own emphasis. See Tracy and Adams (MLR) 806; LRCSA (1985) 9-11; Pawlowski and Brown (PLR) 122-134; Nathan (TLR) 40; Gallanis 189; Yntema (Cor LR) $77 \mathrm{ff}$ and Re (FLR) 482. 


\section{Critique Against Roman Law Presumptions}

The Roman law presumptions have been criticised as illogical rules, based on inappropriate distinctions between deceased victims based on age and gender. ${ }^{37}$ Wigmore dismisses the civil law presumptions which reflect (according to him) 'a rule of continental sort' as 'grotesque false to human nature' and suggests that '[s]ome Monkish jurist of the middle Ages must have been its composer'. 38 Nathan argues more persuasively that the civil law does not narrate modern times and has some imbalances and 'lacks common sense'. He states: ${ }^{39}$

Technological developments have left the Roman Empire behind, and with it the conditions that gave rise to such presumptions. Neither the Romans nor the redactors of the French Civil Code had any inkling of the tremendous developments in the fields of transportation that would come about in the nineteenth and twentieth centuries.

The Roman law was also labelled as complicated, and 'not entirely perspicuous and decisive'. ${ }^{40}$ Conway and Bertsche criticises the Roman presumptions as follows: ${ }^{41}$

The choice of age as the determining factor does have the merit that such fact is easily and definitely established, more so than any of the other circumstantial evidence (aside from sex) usually available in cases of contemporaneous death. Utilization of the less objective circumstances of strength or health as factors determinative of survivorship would necessitate comparisons and a consideration of conflicting inferences which the enactment of such a statutory presumption seeks to avoid.

From a present-day perspective, the Roman law has little influence as most jurisdictions have moved on to a more general presumption based on 'simultaneous death' or the 'no survivorship principle'. In modern time, only a few jurisdictions follow the Roman law principles as moderately reflected in section 184 of the English Land Property Act. ${ }^{42}$ It can be argued that the Roman presumptions have lost their impact as even the Napoleonic code was altered in 2001.

\section{Critique Against Traditional Common Law}

Although the common law's 'no presumption' principle has been described as the most honest of all three the approaches, it was also

37 LRCBC (1982) 7; Nótári and Papp (FJ) 12.

38 Evidence in Trails at Common Law (1981) 620. This remark might be too harsh.

39 (TLR) $33 \mathrm{ff}$. He refers to the position in Louisiana and compare it with the rest of America.

40 Derrett (UCR) 66 argues that it "left a good deal of room for judicial equity, which hampers the descendants of the jurists who do not share their atmosphere or their skill'. See also Hubback 149-150.

41 (FLR) 19-20.

42 See Folkerth (OSLJ) 684. Guernsey released a document Project De LOI 'The Inheritance (Guernsey) Law' 2011 Commorientes and Survivorship Part IV where the order of seniority was reintroduced. 
subjected to criticism. ${ }^{43}$ Factual differences led to different scenarios, depending on the actualities concerning the circumstances of the death. ${ }^{44}$

\section{Burden of Proof}

On the one hand criticism includes critique on the 'burden of proof' as it was adopted in the traditional common law. ${ }^{45}$ Several scholars have condemned the common law as, according to them, it results in an unacceptable state of affairs leaving beneficiaries (who want to prove survivorship) in the unenviable position where they have to prove which person died first or who had survived. ${ }^{46}$ De Beer warns that: ${ }^{47}$

The use of experts in testimony is a very expensive procedure and will only become relevant once a matter has been set down for trial. The whole procedure is time consuming, expensive and, in essence, squandering our courts' time.

It has also been argued that the advances made in medical technology, which allows life to be prolonged artificially in ways that were not possible in earlier historical periods, are contributing to problems with proof in the common-law jurisdictions. ${ }^{48}$

\section{Interpretation of Wills}

The strict interpretation of wills, phrases such as 'if the one predeceased the other', or interrelated clauses such as 'if we die simultaneously' or 'if she dies before I do' have not been even-handed, especially in situations where 'uncertainty' has arisen as to who died first. ${ }^{49}$ Case law such as Underwood $v$ Wing and Wing $v$ Angrave confirmed the 'no presumption' principle but unfortunately interpreted the words in the wills, which made provision for the one spouse to 'die in my lifetime', very literally. 50 Since the beneficiary could not prove that the departed had died 'the one before the other', the claim by the nominated substitute beneficiary was rejected. ${ }^{51}$ The interpretation by the courts of such clauses in wills,

43 In Bennett $v$ Peattie (Ontario case) the common law on survivorship was even regarded as illogical and unsatisfactory. See also Conway and Bertsche (FLR) 17-18; LRCSA (1985) 3-37.

44 See Roeleveld 49 for circumstances that can contribute to the judgement.

45 Casey et al 26-27; Nathan (TLR) 42.

46 See also De Colyar (JSCL) 255-277; Mee (NILQ) 177; Cohen (LLJ); Phillips (Cal LR); Gallanis 189-200; LRCSA (1985) 19.

$47 \quad 10$

48 Gallanis 199; Haneman and Booth (NLR) 451: 'Rapid mass transportation, natural disasters, and multiple homicides are common situations in which a decedent and his heir apparent will perish without clear evidence as to the order of death.'

49 Compare Mee (NILQ) 177 and his discussion of Re Kennedy; Phillips (Cal $L R$ ); Pawlowski and Brown (PLR) $122 \mathrm{ff}$ and Zander 42.

50 See also De Colyar (JSCL) 255-277; Mee (NILQ) 173 for Northern Ireland and Phillips $(\mathrm{Cal} L R)$ for the USA. See also Cohen ( $L L J)$; Gallanis $189-200$ and LRCSA (1985) 19. 
where provision is made for eventualities, therefore became contentious and once again led to statutory interventions. ${ }^{52}$

\section{Terminology}

Contributing to vagueness regarding the common-law principle is the situation that whenever the order of death could not be established (there is uncertainty), the courts rejected the application of presumptions but use terminology such as 'an inference can be made from the fact that they have died together' or 'it is inclined/assumed/presumed that the victims have died simultaneously'. ${ }^{3}$ The use of these phrases is confusing and it has been explained as follows in the Harvard Law Review: 54

The common-law technique is most readily applicable to the situation where two persons, one the heir of the other, perish in a common disaster leaving no evidence of even momentary survival. Disavowing the creation of any presumptions, the courts yet 'assume' simultaneous death and place the burden of proof on that party whose claim of title depends on his proving survivorship. Where no will is involved, the deceased heir is eliminated, and those who claim through him lose because of their inability to bear the burden of proving his survivorship. The property passes to the other heirs of the intestate, who need prove only his death and their own survival. ${ }^{55}$

\section{Criticism of Statutory Intervention}

As seen above, the statutory intervention in certain jurisdictions was a direct result of the difficulties that have arisen with the onus of proof, joint tenancies and testamentary clauses. ${ }^{56}$ Unfortunately, the reform in England grasps back to the Roman 'presumptions' as it provides for the younger victim to have survived the older victim. It is argued that the very purpose of enacting legislation is to reach some conclusion, which inevitably will be more or less arbitrary, regarding the distribution of property. ${ }^{57}$ The English provisions differ from their American equivalents which rely more on guidance from continental law.

51 See Orji $(C P L)$ 503-504. See the cases Underwood $v$ Wing; Tucker $v$ Shreveport Transit Management Inc 226 F 3d 394 CA, 5th Circuit 2000; Greyling $v$ Greyling 19782 SA 114 (T). See Murray 364 for a detailed discussion of the latter case where it was argued that if the one spouse is nominated as a beneficiary and survives the first dying (even for a very short time) the rights to the estate of the first dying had vested in the survivor and should be channelled through the 'initial survivor' to his or her heirs and not to the first dying person's heirs.

52 As seen above. See Tracy and Adams (MLR) 806; LRCSA (1985) 9-11; Pawlowski and Brown (PLR) 122-134; Nathan (TLR) 40; Gallanis 189; Yntema (Cor LR) 77 ff; Re (FLR) 482.

53 Own emphasis. See also Tracy and Adams (MLR) 806; Schoeman 181; Van Heerden et al 56; De Beer 8 and LRCSA (1985) 8-9.

54 See 343

55 Own emphasis.

56 Folkerth (OSLJ) 684; See Leete $v$ Sherman where it is explained that legislation has its origin in the problematic administration of the commonlaw rule. England and Wales already adopted legislation in the early 20th century. 


\section{English Law of Property Act}

Section 184 of the English Law of Property Act was soon widely condemned as it does not satisfy 'all circumstances' and assumingly lacks an actual basis in human experience. ${ }^{58}$ It has been described as 'an arbitrary solution' to the problem of determining the order of death. ${ }^{59}$ Allegedly the scope of the presumption is too wide, as it applies for 'all purposes effecting the title to property' (including property held in joint tenancy), ${ }^{60}$ and it has some restrictions as it only applies to 'cases of uncertainty' and is 'subject to a court order'. 61 Both these phrases have been criticised. Lord Walker makes the following barefaced remarks in this regard: 62

But I must come back to section 184. What is the significance of 'subject to any order of the court'? Does it give the court a discretion to displace the default rule if it would be fairer, or more sensible, to do so? That suggestion was firmly rejected in Re Lindop, so establishing the cold-blooded nature of the presumption. Bennett J also decided, following Lord Campbell and taking what may seem rather a Lincoln's Inn approach, that since time is infinitely divisible, he could not hold that a husband and wife died simultaneously in a wartime air-raid even though the house where they were in bed was completely destroyed by a direct hit.'

However, Gallanis has argued that a statutory presumption (along the lines of section 184) might have a distinct advantage over the common law position '... because the common law, by leaving the possible sequence of deaths open to argument and practically invites litigation'. 63

57 Conway and Bertsche (FLR) 19-20; Benas and O K F $(M L R)$ 88; see Tate 'Inheritance and Presumptions' 2010-07-01 Trusts and Estates Jotwell states: 'Since the mid-twentieth century, widely adopted uniform acts have attempted to solve the puzzle of simultaneous death by establishing a presumption of survivorship. Yet this was not always the case'. See also Zander 132-139 and 142. De Beer 10 and Walker (SLSC) $5 \mathrm{ff}$.

58 HLR 346-347; Walker (SLSC) 5; Zander 132-139 and 142.

59 Similar presumption applied in Louisiana and was also criticise. See Haneman and Booth (NLR) 451-471. See also LRC 70-2003 Ch 3; LRCSA (1985) 11 also repudiates s 184 . Mee (NILQ) 171.

60 See also Walker (SLSC) 3: 'That is no doubt why Parliament changed the law, in 1952, for the limited purpose of intestate succession between espouses. Otherwise the combined wealth of a young couple who died together on their honeymoon would tend to end up with the family of whichever happened to be the younger.' See also Kerridge 343 and Sawyer and Spero 156.

61 Re Lindop, Lee-Barber v Reynolds; Re Kennedy; Phillips (Cal LR); Pawlowski and Brown (PLR) 122 ff; Mee (NILQ) 177 ff; Orji (CPL) 506 and Zander 42; Casey et al 26-27; Nathan (TLR) 40; Nótári and Papp (FJ) 19.

62 3. See also Victoria Law Reform Commission "Amendment to Outdated Provisions' Ch 6 and Victoria Law Institute § 44. 'Section 184 should be amended to omit the words "subject to any order of the Court" and to substitute the words 'unless a court otherwise orders.'

$63189 \mathrm{ff}$ stating that a presumption gives a firm starting point and can be displaced only by positive evidence. See also Hubback 150; Wislizenus $(S t L R) 1$ (argues in favour of civil law presumptions). 
From a South African perspective, De Beer describes the presumption in section 184 essentially as one of convenience, with no firm basis in probability. ${ }^{64}$

\section{Other jurisdictions}

Despite legislation in most jurisdictions which makes provision for situations (including joint tenancies) where uncertainty surrounds the order of deaths of people, some additional problems with the application of 'the simultaneous deaths' doctrine have surfaced. ${ }^{65}$ These problems stem from certain testamentary clauses that one finds regularly in wills of spouses or relatives. On the one hand, testators often make provision for 'gift overs' if it is foreseen that the instituted beneficiary might predecease the testator. ${ }^{66}$ On the other hand, testators often anticipate possible simultaneous deaths in common disasters or catastrophes. ${ }^{67}$ Gorgopa explains the motivation for people to make provision in their wills for such eventualities: 68

It is common for spouses to make mutual or reciprocal wills by which each spouse makes provision for the other and then specifies a scheme of distribution that is essentially identical in both wills, with the intent that the scheme of distribution will operate only once on [sic] the last of them to die.

Both of these types of testamentary clauses, dealing with either successive or simultaneous deaths, have often come into consideration not only by the courts but also by legislation. ${ }^{69}$ The interpretation of such clauses indeed prove to be problematic, as the courts tend to interpret the word 'predeceased' and related phrases such as 'simultaneous death', or 'die before me' strictly and literally. ${ }^{70}$ Derrett warns against dispositions drafted to provide for the contingency of two persons dying 'simultaneously' or 'contemporaneously': 71

This is a mistake, for if it is not possible to prove that the death was actually simultaneous, etc., as is usual, the condition cannot operate. In one of the more interesting cases on the subject of commorientes arising in the last halfcentury this was pointed out strikingly.

6410.

65 See the discussion above in paras

66 Kimbrough (W\&M L Rev) 269; LRCSA (1985) 6; Underwood $v$ Wing 664-665; Wing $v$ Angrave.

67 Murray 363-364; Gorgopa; Orji (CPL) 503-504.

68 See Underwood-case; Wing v Angrave; Re Rowland: Smith v Russell; Estate Greenacre v Brett 1956 (4) SA 291 (N); Greyling v Greyling; Gray v Sawyer; White $v$ Taylor 286 South Western 2d 925 (Texas 1956); Estate of Rowley Cal App 2d $324332-335$ (1967); In re Estate of Schmidt; Re Fair; Collins v Becnel.

69 In this regard reform was considered in America (UPC), Canada, Australia and New Zealand. See the $L R C B C$ (1982), which in turn drew on the USDA.

70 See Underwood-case; Wing $v$ Angrave; Re Rowland: Smith $v$ Russell; Estate Greenacre v Brett; Murray 363-364; Gorgopa; Orji (CPL) 503-504.

71 (UCR) 59. 
If it has been found that the couple did not die momentarily together, ${ }^{72}$ the alternative provision fails to take effect, because the sequence of deaths did not occur (precisely) as stipulated in the wills. ${ }^{73}$ This could result in a situation where potential beneficiaries find that they were treated differently based on the length of the interval between the deaths of testators.

In this regard it has been advocated that when the courts interpret testamentary clauses they should take into account the testator intention, for property to pass to a person and through a person who survives him, ${ }^{74}$ even only by a split second. ${ }^{75}$ In this regard Nathan makes the following submission: ${ }^{76}$

A provision in the will for a gift over, however, reveals the inadequacies of the common-law rule, for a strict adherence to it defeats such gifts by making fatal the inability of the beneficiary under the gift over to prove the nonsurvival of the primary legatee, which is a condition precedent to the vesting of his own interest. This is the result reached in the English cases even where the two unfortunate testators had, after leaving their property each to the other, made identical provisions, conditioned upon the non-survival of such other, for a gift over to a third person.

Several jurisdictions revert to profound statutory measures. ${ }^{77}$ In most common-law jurisdictions attempts to resolve these matters include adopting legislation to regulate situations where there is no sufficient evidence to substantiate the sequence of deaths (also known as delay clauses). ${ }^{78}$ Folkerth explains that the intent and effect of legislation has been that the property which belonged to the deceased prior to his death,

72 Corbett et al 547-548; Murray 363; Orji (CPL) 502.

73 See Gorgopa; Estate Greenacre v Brett; In re Pringle; Re Rowland: Smith $v$ Russell. The court held that the spouses' deaths had 'coincided' within the terms of their wills, since it was quite possible that one had survived the other by some period of time. The bequests in the wills were therefore of no effect.

74 Haneman and Booth (NLR) 464: 'The stated purpose for this revision was to distribute property in a 'manner most consistent with the decedent's intentions and to avoid litigation over the precise time of death in common accident cases". See also LRCSA (1985) 3.

75 39. See also Zadnik 74; Saslaw 60; HLR 345 and Gallanis 197.

76 (TLR) 40.

77 Phillips (Cal LR); Provence 101. The testator(s) can provide in estate planning documents (such as a will) for a longer survivorship period, such as 30 days. Coffey and Long 1315 explains: 'A major change under the Succession Act is S 35 which states that if a gift is made to a person who dies within 30 days after the will-maker's death, the will is to take effect as if the person died immediately before the will-maker. It is however possible to exclude that provision from your will or to lengthen or shorten the 30day period.' See also $L R C B C$ (1982) $1 \mathrm{ff}$.

78 The first anti-lapse statute was enacted in Massachusetts in 1783. The English Statute of Wills of 1837 contained an anti-lapse provision that limited its coverage to devises to children or other issue of the testator. 
shall descend to his respective heirs at law. ${ }^{79}$ If the survivor does not live beyond the death of the other victim for at least the time stipulated in the applicable statute, then neither victim is regarded as a survivor, and they are considered to have died simultaneously. ${ }^{80}$ If the survivor does actually live for at least the stipulated time, following the death of the other, it is assumed that he or she survived the first deceased. ${ }^{81}$ Kimbrough clarifies the anti-lapse statutes: ${ }^{82}$

Beginning in the late eighteenth century, legislatures in the United States and in Great Britain began to counter this harsh result by crafting statutes that would protect certain devises from lapsing. These statutes, commonly referred to as 'antilapse' statutes, provide that when a devisee within a particular class predeceases the testator, the devise does not fall into the residue or pass to the testator's heirs by intestacy but descends to the issue of the predeceased devisee.

South Africa has no legislation that makes provision for a period of delay before a survivor can inherit. It remains a factual question to establish the sequence of death and then to interpret the will of the deceased to establish the meaning of the 'words' they used. ${ }^{83}$ When the court had to decide on a similar clause in the South Africa case Greyling $v$ Greyling, it held that the words 'to die simultaneously' mean the death of the testators as the result of a single incident, irrespective of the fact that there was a difference in the exact time at which they each died. ${ }^{84}$ As there are no presumptions in South African law regarding the order of deaths the court found that the words in the wills refer to a single occurrence. Murray explains the South African position on such clauses as follows: 85

Because of difficulties of determining whether the deaths are 'simultaneous' so as to bring into play the alternative provisions for devolution of the bequest

79 Kimbrough ( $W \& M L$ Rev) explains it as follows 275: 'The position is materially different if given the tragic accident where both parties die and are married but both are intestate i.e. they have not made a Will at the date of their death. The rule that the elder survives the younger is not imposed. If it is not possible given these circumstances to establish who survived, then neither spouse will take an interest in the estate of the other i.e. the husband's property on death will fall to go to his children or other relatives and the spouse will likewise devolve her property to her children'.

80 Orji (CPL) 502; Sawyer and Spero 27. See LRCBC (1982) 7 where reference is made to Re Warwicker, a 1936 Ontario decision. See also In re Pringle.

81 Estate of Villwock 142 Wis 2d 144 (1987) 418 NW 2d 1 (Wisconsin Court of Appeals); Re Kennedy; Tucker $v$ Shreveport Transit Management Inc; Ex parte Martienssen; Hickman $v$ Peacey; In re Pringle; Ex parte Chodos.

82 (W\&MLRev) 269

83 S 2C(2) of the Wills Act makes provision for a descendant of the testator: ‘... whether as a member of a class or otherwise, would have been entitled to a benefit in terms of the provisions of a will if he had been alive at the time of death of the testator... the descendants of that descendant shall ... per stirpes be entitled to the benefit, unless the context of the will otherwise indicates'.

84 Murray 364 ff. Estate Greenacre v Brett was criticised by Murray. For the same approach see Underwood $v$ Wing.

85365 
- a frequently - used form of will specifies some period of time for survivorship or non-survivorship, for example that the alternative provision is to take effect should the testator and the named beneficiary either die at the same time, or within, say, one month of each other.

It has been argued that the approach adopted in Greyling's case is seemingly more acceptable than the strict 30 days or 120-hours approach that can fail to give effect to the testator's or testators' wishes. ${ }^{86}$ However, the potential for possible unintended consequences can be significantly reduced or eliminated through careful planning and the implementation of a comprehensive estate plan. 87

\section{Conclusion}

If all the criticism is taken note of it becomes understandable why the 'commorientes' doctrine remains contentious. ${ }^{88}$ From the discussion above, it becomes clear that the foundation and historical differences between civil law and common law principles are mirrored in the 'commorientes' doctrine. Tetley summarises it as follows: ${ }^{89}$

A major difference between the civil law and common law is that priority in civil law is given to doctrine (including the codifiers' reports) over jurisprudence, while the opposite is true in the common law.

In the evaluation of the formalistic civil law as opposed to the casuistic common law approaches toward 'commorientes' it becomes apparent that there are by and large some similarities in the different systems. Firstly, when the sequence of deaths can be established the division of the estates will follow the order as proved; and secondly only when a dispute arises or when there is 'uncertainty' that surrounds the deaths of related people, the courts are called upon to establish the sequence of death. ${ }^{90}$ Then again, the dissimilarities between the civil law and common law are reflected in the approaches towards 'commorientes' and are typical of the different legal systems. Neuhaus explains it as follows: ${ }^{91}$

The former aspect calls for legislation, the latter for judicial decision. It has often been said that legislation corresponds to the abstract and systematic mode of thought of continental Europeans, while judge-made law is more suited to the practical and empirical style of Britons and Americans. Indeed, in England as well as in the United States, even statutes are generally directed

86 See Gallanis 200 argues that in light of technology, a rule that makes the outcome depend on survival by 120 hours might not adequately take into account the incentives that some heirs and devisees may have? Leete $v$ Sherman for the application of the rule.

87 See Corbett et al 547. See however Tucker v Shreveport Transit Management Inc.

88 Tate. See also Walker (SLSC) 5 ff; Benas and O K F (MLR) 88; Zander 132139 and 142 .

89 (ULR) 613.

90 Own emphasis.

91 See Neuhaus 795: 
not so much to general regulation in comprehensive terms, but rather to caseby-case solutions of separate situations. ${ }^{92}$

However, regardless of whether presumptions are used, or not, it remains a daunting task to establish the exact order of death. ${ }^{93}$ Two further worrying issues regarding 'commorientes' remain. Firstly, it has become clear that the courts are accepting the slightest tad of evidence indicating survival, to find that simultaneous deaths did not occur. ${ }^{94}$ The second issue is that the outcome of the distribution of an estate can depend on survivorship by seconds. ${ }^{95}$ Tracy and Adams, already in 1940, suggested that the concept of inheritance of property based on survivorship of mere minutes or hours is offensive to many. ${ }^{96}$

An assessment of the doctrine of 'commorientes' has shown that the differences between traditional English common law and English statutory law are evident (the 'no presumption rule' versus the 'presumption'). ${ }^{97}$ However, the differences between the continental approach of 'presumptions of no survivor' (as reflected in most civil codes) as opposed to the English common law approach of 'no presumptions' is more perplexing because in both systems the outcome can be the same. In both systems, the victims are regarded as being unable to inherit from one another either because they are looked upon as being predeceased or because they are regarded as not having survived each other.

The position in South Africa is unique as it rejects Roman civil law, Roman-Dutch law and the English statutory advances. However, when all the historical approaches and modern day developments are assessed, it can be concluded that South Africa has adopted the traditional English common law approach (as it was before 1925) based on the so-called "no presumption' rule. ${ }^{98}$

In this regard De Beer argues that although through section 184 the shift seems to be towards legal certainty, the basic question of feasibility still remains unanswered. He states: "It is safe to infer that in the United Kingdom, the position on commorientes has undergone a paradigm shift

92 See Wigmore 620. The fundamental difference identified between the civil law approach and the traditional common law approach is reflected in the presentation of evidence to ascertain whether 'simultaneous deaths' occurred. See also HLR 344.

93 Middleton JA in Bennett $v$ Peattie said: 'There is no way by which a division of the property can be secured unless the common sense of the contending factions triumphs over the desire to litigate'. Ontario Court of Appeal. See also Tracy and Adam 807.

94 Own emphasis. See also Thomas $v$ Anderson; Smith $v$ Smith 229 Ark 579 (Arkansas 1958).

95 Own emphasis.

$96(M L R) 801 \mathrm{ff}$.

97 Most jurisdictions have made attempts to replace 'presumptions of survivorship' with workable and equitable rules.

98 Case law however, does not really refer to any authority. See Corbett et al 5. 
from relying on common law presumptions towards reliance on legislation'.

It is noteworthy that there is often, throughout all approaches toward the 'commorientes' doctrine, ${ }^{99}$ an undertone of an equitable approach. ${ }^{100}$ Derrett refers to the reception of presumptions as follows: ${ }^{101}$

Where the court has to elect between the rigid application of a rule of the old law to a case not clearly contemplated by that law and the application of an equitable principle which does not defeat the old law but prevents any injustice from its rigid application, the court would be quite justified in choosing the latter alternative.

The traditional common law approach of 'no presumption' was also regarded as equitable but came under suspicion due to the literal interpretation of 'simultaneous deaths'. Phillips explains the adoption of legislation so as: ${ }^{102}$

... [t]o supplant the former arbitrary and complicated presumptions of survivorship with effective, workable and equitable rules applicable to the everincreasing number of cases where two or more persons have died under circumstances that there is no sufficient evidence to indicate that they have died otherwise then simultaneously. ${ }^{103}$

Roeleveld in his discussion of the South African position explains that all systems (civil and common law) have the purpose of serving equity and achieving certainty: ${ }^{104}$

The question is to be considered if all these presumptions are still valid in the changed circumstances of the present rate of morality, the higher average age of human beings, the higher average age of women in comparison with men $\ldots$ and the same in connection with climatological circumstances, the probably higher rate of traffic accidents and the lower rate of accidents on the high seas, etc.

It appears from South Africa case law, that a general equitable approach is followed when dealing with 'simultaneous deaths'. ${ }^{105}$ As seen above the court in Ex parte Graham rejected the presumptions because '... it [is] not necessary or desirable to slavishly follow such completely artificial reasoning in modern times'. Roeleveld tends to agree with the opinion of

99 Case law will be discussed in another contribution.

100 Du Toit 285 explains that in virtually every aspect of Roman-Dutch law one will find equitable principles and remedies which give concrete expression to its underlying concern with justice and fairness.

101 (UCR) 64 fn 17.

102 (Cal LR). He refers to Azvedo v Benevolent Soc of Calif. See also Belkin 101.

103 Own emphasis. See also Provence; De Beer 10: 'It is safe to infer that in the United Kingdom, the position on commorientes has undergone a paradigm shift from relying on common law presumptions towards reliance on legislation'.

104 49. He refers to the opinion of Völker: ' $\ldots$ the Roman Law had more reasonable results and emphasises equity more than probability'.

105 Own emphasis. 
modern writers that the courts should have a discretion (after considering the facts) in the matter of 'commorientes'. 106

In the South African context, De Beer has made some recommendations regarding 'simultaneous deaths'. ${ }^{107}$ Firstly, he recommends that 'death' should be defined as 'brain death' and that 'time' should be considered in relation to the occurrence of a common event in which two or more people die simultaneously or as a result of which they incur fatal injuries. He further suggests an amendment to the law of succession by stating the following:

Incorporating the French position (the presumptions) with that of New Zealand (the burden and degree of proof) and the United States (provisions of the Simultaneous Death Act) would seem to be the best solution for all the questions hanging over the head of modern laws of succession. A further qualification of the new procedures would require a person who aims to prove the contrary of simultaneous death to render sufficient security to ensure that no assets of the estate would be used in either instituting or defending such an action. ${ }^{108}$

In my opinion these recommendations might be too much of a giant leap and over ambitious in a jurisdiction such as South Africa which has no statutory basis for the 'commorientes' principle and claims not to follow the Roman or Roman-Dutch law. There is, furthermore, no clarity whether statutory provisions have any real advantages over the common-law principles. ${ }^{109}$ It seems from reported case law that in jurisdictions where presumptions are used to prove the order of deaths, the focus has shifted from 'have the victims died simultaneously' to 'is there uncertainty as to the order of death'. Bottom of Form

The proposal by the Law Reform Committee of South Australia is supported:

In dealing with the remit we have reached a similar conclusion to that expounded by Wigmore as early as 1934, namely that the problem of survivorship should not be dealt with by making a rule of evidence to cope with the uncertainties of proof but rather by making a rule or rules tending towards a fairer distribution of property and more in accord with the likely wishes of the testator.

106 He refers to Hoffman South African Law of Evidence (1963) $97^{\prime} \ldots$ but if it is uncertain which of two persons died first, there is probably no rule requiring the court to presume that their deaths occurred in any particular order'. Reference is made to Voet 3453 and 36116 . He refers to 'the usual practice to make an order presuming that they died simultaneously'.

107 41-42. See also In Re: the Estate of Byron Keith Miller No 2002-CA-00231-SCT (2003): 'That aside, courts have consistently held that under the equitable doctrine that 'equity follows the law, courts of equity cannot modify or ignore an unambiguous statutory principle in an effort to shape relief'.

108 De Beer 41 in addition, proposed a further qualification, namely that in the event of a person being in a state of unconsciousness (a coma), he or she has to be considered to be alive until death or resurrection.

109 Nathan (TLR) 42. 
It seems as if the 'prophesies of justice' in the Holy Bible that Roeleveld referred to in his conclusion on 'commorientes' remain true: ${ }^{110}$

All the attempts of legislators, courts and lawyers to find justice and equity in relation to commorientes must be seen in this light. My conclusion is that the law of succession must be sober, not complicated, because it is not given to man to foresee every legal and factual possibility and to anticipate them by strict rules. There must remain sufficient room for case-law, fully based on equity.

In conclusion, I tend to agree with the view that in many instances the common law (factual question and interpretation) appears to provide a more satisfactory solution to the survivorship problem than any strict presumption such as section 184 of the English Law. ${ }^{111}$

110 He refers to Ecclesiastes 7:16-17. The New King James Version (NKJV) reads as follows 'Do not be overly righteous, Nor be overly wise: Why should you destroy yourself? Do not be overly wicked, Nor be foolish: Why should you die before your time?'

111 See also Hubback 150; Mee (NILO) 181. This is also the view taken by the Law Reform Committee of South Australia: 'On the other hand, the presumption will not be invoked if evidence is adduced which in fact establishes the precise order of death, because in such a case the circumstances will not render it uncertain who survived the other or others.' 